\title{
PHILOSOPHY OF EDUCATION
}

\author{
UDC 159.923.2 : 37. 015.311 \\ DOI: https://doi.org/10.30839/2072-7941.2019.165103
}

\section{IDENTITY AS A RESULT OF THE SELF-DETERMINATION OF THE PERSONALITY IN THE EDUCATIONAL ENVIRONMENT}

\author{
(C) YULIIA, VASYUK \\ Postgraduate student of Bohdan Khmeynytsky Melitopol State Pedagogical University, \\ (Melitopol, Ukraine) \\ E-mail: 617811@ukr.net ORCID iD: 0000-0002-5296-4851
}

\begin{abstract}
Topicality is due to the fact that self-identity as the identity of the subject and the result of its self-determination now is explained with the two-sided ascent of human to freedom, when at first the subject realizes the need for self-disclosure of its own essence, the embodiment of human nature, and then it overcomes its dependence from its internal nature and the generation of identity begins as a manifestation of free will and creativity of the person of culture. The purpose of the study is to clarify the essence and the meaning of the personality identity as a result of its self-determination in the educational environment.

Objectives of the research: distinguishing of the lines of theoretical interpretation of the personality identity; the characteristic of identity as a form of personal being in the educational environment, which ideally integrates the inner world of a person and its external world into a single psycho-social universe on the subjective level; clarification of the fundamental aspects of the personal identity understanding, its main factors within the framework of the common structure of the educational environment; consideration of the phenomenon of identity from the point of view of the subject in the context of the problem of intersubjectivity. An analysis of recent research and publications that initiated the solution of the problem: the use of articles by the authors Bart R. (1987), Weber M. (1998), Ilenkov E. (2010), Klepko S. (2005), Kultaieva M. (1988), Oleksenko R. (2013).

Scientific novelty is contained in the identification of the high role of interaction in the educational environment on the intercultural level, which is conditioned with the general attitude towards the subject as a representative of one or another group of the educational process subjects, in the distinguishing of the content range of identity (a peculiar educational epicenter of the life cycle of «person of culture» as the subject of educational processes; selfreference; the unity of constancy and variability; the personality awareness of its belonging to one or another social and personal position in the context of social roles the educational environment; originality and peculiarity; identity, equivalence; proportional correspondence; essential similarity; coincidence; self-identification with norms and values of the educational environment, its specific level).

The results of the research: the person is determined to be the center, the subject of the educational environment, whose positive changes can help to talk about the effectiveness of this environment, when it as an essential element of society becomes a self-organized and managed multifunctional open pedagogical system, within which a personality recognizes oneself as a socially developed integrity.

Conclusion: identity as a result of self-determination of personality in the circumstances of the educational environment arises as a problem of finding of the meaning of life and of person oneself in the domain of sociocultural and personal values. It is the concept that gives an opportunity to analyze this environment from the point of view of the effectiveness of the growth of self-awareness and subjective activity of its participants.
\end{abstract}


Key words: person of culture, educational environment, self-determination of the personality, identity, content range of identity.

\section{Topicality.}

Social philosophy of the twentyfirst century, having reoriented from subject-centeredness to the communicative-discursive field of research, focused its attention on the study of a person in its relation to the environment in which it exists, and hence on the question of the formation of self-consciousness of a personality in conditions of communicative space. Due to these circumstances, in the context of the research problem, the important aspect of the phenomenon of personality in the educational space is the question of its identity as a complex personal formation, which has a multi-level structure, connected with three basic levels of human nature analysis: individual, personal and social; at the same time, the concept of «identity» defines a system of values, a certain reference point of world-view orientations of a person, the position that personality proclaims, and recognition of this position, especially in the educational environment.

Formulation of the problem. If self-determination is the designing and development of a way of life, then the result of this activity is identity as a category of self-consciousness, which is generated with experience and communication and considered by us as an independent and conscious acquirement of personal senses. As a result of the processes of personal self-determination, personalization and self-organization, developing on the basis of awareness of the personality oneself as a representative of a certain group in the educational environment, there is identity arises as a stable concept, which reflects the relationship of cognitive, motivational and value personal characteristics that provide orientation and interaction in the space of existence of the personality, allow to realize the personal potential more fully, as well as to predict possible directions of one's own development.

Self-determination of the personality in the form of identity is accompanied by a change of the person's perceptions about itself, one's own place in the social world, the acquisition of his or her social status. For example, many scientists have proved the close connection between personal self-determination and professional identity.

Analysis of recent research and publications. It was revealed that the research of the peculiarities and regularities of personality formation was conducted by scolars in the context of scientific searches in the area of mentality and mentalities problems (A. Gurevich, M. Kagan, K. Sokolov, Yu. Solonin), identification and self-identification (M. Gubolgo, G. Knabe, E. Trubina, A. Sheman), intercultural communication (M. Bakhtin, P. Bourdieu, T. Van Dijk, M. Moss, G. Pocheptsov).

Significant conceptual achievements in relation to the content aspects of the problem under study is related to the anthropological tradition (R. Benedict, A. Kardiner, K. LevyStrauss, B. Malinowski, E. Taylor) 
and related socio-anthropological and ethnomethodological (I. Geysinga, G. Garfinkel, P. Bourdieu), historical (F. Broudel, J. Le Hoff, A. Toynbee, O. Spengler) schools. Social phenomenology

B. Waldenfels,

T. Lukman,

(P. Berger,

Mamardashvili, M. Scheler, D. Walsh) focuses on the holistic image-representation of the individual about itself in all life situations, as well as in correlating oneself with a particular social group or society as a whole. Social philosophy and methodology of social sciences (H. Abels, Y. Habermas, D. Becker, E. Giddens, N. Louman, T. Quinn, T. Kuhn), as well as researchers of the post-Soviet space A. Akhieser, V. Inozemtsev, V. Kemerov, T. Kerimov) consider a person in the context of transformational social change.

The development of education in Ukraine became the subject of intensive scientific research, reflected in a large number of works on pedagogics, sociology, psychology and social philosophy (V. Andrushchenko,

I. Bekh,

M. Boguslavskyi,

L. Huberskyi,

V. Kremen,

V. Hromovyi,

K. Korsak,

M. Kultaieva,

E. Pinchuk,

R. Oleksenko,

D. Dzvinchuk,

P. Kononenko,

O. Kotliarova, V. Lugovyi,

I. Predborska,

G. Stasiuk, I. Stepanenko, T. Troitska etc.). The concept of identity has a rather long history and was used by many theories, although the theoretical and empirical development of the problem of identity began in the XX century.
In cultural anthropological theory the concept of the basic personality (A. Kardiner) was close to its content. In its epicenter there was the way to behave and interact with other people, which is common for people of one social group. At the same time, the notion of identity is widely based on the role theories of personality, within which it is understood as a structural set of different roles internalized in the social process of learning.

The purpose of the article is to clarify the essence and meaning of the personality identity as a result of its self-determination in the educational environment.

Presentation of the main material.

The characteristic of the modern subject of educational processes is the freedom of choice, the ability to choose one's future and oneself. This choice may turn out to be unexpected even for the subject itself, because there is a transformation, recoding of the sense, the affirmation of one's own values, an opportunity to become different, something more than it is appears. There has a place the transcendence, the meaningful filling of a person, its ascension to the Absolute. During the analysis of the sources we found that the selfidentity, in contrast to the identity of the object, is the identity of the subject.

The subject must not only have identity, but also understand it correctly, because in self-identity there is a two-way ascent of a person to freedom: at first the subject understands the need for selfdisclosure of its own essence, the 
embodiment of human nature. Then there have a place the overcoming of dependence from one's inner nature by the subject and the generation of identity begins as a manifestation of free will and creativity.

An important argument for our research is that a person realizes its identity, thinking about oneself through the language acquired in the process of social interaction. Thus, the conscious identity eliminates the autonomy of the personality from society; it is formed by means of communicative categories produced in language and other communications.

Distinguishing the conscious and unconscious identity, the latter is considered to be the resulting effect of social automatism, such as habitus, stereotypes, norms, etc. G.H. Mead put the personal transformation to conscious identity into the dependence from the comprehension of one's life by the individual and reflection on the occasion of challenges of destiny and problematic aspects (Mead, 1994).

At the same time, the presence of a conscious identity in the educational environment means the relative freedom of the personality, because it stops to be afraid of the ritualized deployment of actions and begins to think about the purpose and tactics of one's own behavior, as well as about the personal result of educational activity.

Identity is also considered as personal conscious experience of one's own ability to integrate all identifications with inclinations, with mental abilities, acquired in the process of activity, with favorable opportunities, social roles, and so on. There are distinguised two the most widely represented lines of theoretical interpretation and the empirical research of individual identity: the first one can be attributed to the current psychoanalytic direction (the authors working in this paradigm rely on the identity theory of E. Erickson, who interprets the identity as a complex personal formation entity having a multilevel structure, linking it with three main levels of human nature analysis: individual, personal and social).

In particular, on the first, individual level of analysis, identity is defined as the result of a person's awareness of one's own time duration, as an idea of oneself as some relatively unchanging giveness, the subject of a particular physical format, temperament, and dispositions, which has some experience of the past and aimed to the future (Erickson, 2006b).

From a personal point of view, identity is a sense of the person's own originality, the uniqueness of one's life experience, which sets the identity to oneself (this identity structure is considered as the result of the hidden work of Ego-synthesis, as the form of integration of Self, which is always something more than a simple set of child identifications).

Thus, identity is the personal construct that reflects the internal solidarity of a person with social, group ideals and standards, which helps in the process of Selfcategorization: these are the characteristics through which people divide the world into similar and dissimilar to themselves. The second 
line of research is based on the G. Mead Self-concept and combines representatives of interactive and cognitive approaches.

Considering identity as a form of personal being in educational environment that ideally integrates the inner world of person and the outside world into the single psycho-social universe on a subjective level, we consider as the principal aspect of personal identity understanding the fact that the main factor that determines this dynamics, the driving force is the dialectical interaction, interdependence and mutual influence of the mentioned psychological and social features within the framework of the common structure.

Self-consciousness of the personality at all theoretical levels of the educational environment contains as one of the most important components the formation and comprehension of the complex of personality attitudes to space and time, which are determined with the forms of existence of the external, and sometimes (or, at least, partly) of the inner world. R. Bart perceives the essence of self-consciousness in a set of key meanings, symbols and value orientations, through which the social group realizes its distinction «from others» (Bart, 1987); E. Ilenkov emphasizes the mismatch of the real personality and its consciousness; he regards the latter as only an attribute of personality, accusing it for «sins of bias» (Ilenkov, 2010); A. Maslow distinguishes five levels of needs and target priorities of a person: physiological; safety and selfpreservation; communication and love; self-affirmation and recognition; self-actualization.

Despite the fact that the needs of the lower level are dominated, that is, they are satisfied by the person first of all, he considers the self-actualization as the most important need - the desire for self-expression, the realization of its potential and permanent self-improvement (Maslow, 1991). From these positions, it follows that self-actualization is a meaningful marker that distinguishes a person from an animal, makes it a person of culture, self-identified person.

Today nobody doubts that communication is a certain intermediary between a person and a society; therefore, in the context of solving the problem of selfidentification of the personality we distinguish the philosophical position which, due to the social character, reflects the basis of communicative action. Examining various aspects of the problem of identity, such prominent thinkers as M. Heidegger, M. Buber, H. Arendt gave the crucial importance to communication, which, according to their belief, is the basis of self-consciousness.

According to Y. Habermas, the principled difference of communicative action against all other types of actions consists in the fact that it focuses not on the success, but on the search for mutual understanding between different social subjects. At the same time, each of these subjects is the bearer of a certain system of values, which are coordinated by social mechanisms of the spiritual area of society 
(Habermas, 1995). If there are value conflicts, which at one time were clearly depicted by M. Weber (Weber, 1998), then they are conflicts between the values of the ethical, aesthetic and religious areas, constituting an integral part of social life, forming the content of identity.

Consideration of identity from the point of view of the subject implies that identity is primarily related to the problem of intersubjectivity, namely the identity of the subject depends on the attitude to the Other («nation», «motherland», «system of education», «students», etc.) as in the sense of a social symbolic structure, as well as in the sense of another particular subject.

This means the high role of interaction in the educational environment on the intercultural level, which is caused with the general attitude to the subject as to a representative of one or another group of the educational process subjects.

The awareness of one's own identity in the educational environment involves identification of oneself, demarcation of one's own meaningful, essential limits, as well as the distinction of oneself from other identities, that is, the determination is not only due to identification with another, real or imagined, specific or generalized, but also by identifying a significant difference between oneself and other (others).

Identity is considered as a diverse phenomenon, which has a complex structural organization and performs various functions - as sociocultural (continuity of generations, uniting of a social group, etc.), as well as individual psychological (selfdetermination, self-realization).

Identity of the person to itself reproduces a person of culture in all its self-identity, moreover reproduces it in the same completeness or cavity as it is itself, and also reproduces being in those parameters in which it is essential and non-random.

Mostly in identity there are distinguished the target, content and axiological components that are in interaction and interconnection. It is possible to outline the wide content range of identity, the separate cognitive accents of which are not contradictory and do not deny, but complement each other invariantly. So, the identity is:

- self-reference, that is, the feeling and awareness of the uniqueness of one's own self;

- the unity of constancy and variability, which creates the foundation of a combination of social renewal with continuity with giving the individual a possibility of selfdesign, changing and modifying with the individual in time;

- personality awareness of one's belonging to one or another social and personal position (status, function) in the context of the social roles of the educational environment;

- a kind of educational epicenter of human life cycle;

- categorization as the definition of the essential and ontologically relevant affinity with a certain existential marker or trend (social, axiological, ethical, cultural and civilization, educational, etc.); 
- the answer to the question whether the subject of educational processes is the «person of culture»;

- originality and peculiarity;

- identity, equivalence, proportional correspondence, essential similarity, coincidence, consistency;

- in varying degrees articulated, acutely and intensely experienced by the individual, group, and society, the sense of their belonging to «their» world, self-identification with the norms and values of the educational environment, its specific level: a substantial, well-established Self of the person, the ideas of the individual about oneself, «Self-image», through the prism of which a person perceives itself and the world around, some integrity, unity, the totality of definitions of «Self», which is understood as a dynamic identity, that inherently changes as a result of interaction with the outside world.

Identity is considered as:

- a way to think about a person in a modern society of knowledge;

- awareness of oneself as an individual in its physical form, surrounded with certain significant Others in one's culture and society, that is an awareness of one's own personality;

- a sense of the integrity of one's personality, the continuity of one's own biography;

- awareness of one's own essential, objective affiliation to the particular social group, in various areas of social experience;

- distinguishing of the personality characteristics which are relevant for this research, for example, «identity in the educational environment».
When the theoretical levels of the educational environment are considered, nowadays there is a need to take into account the cultural markers - global and national levels of cultural representations of educational centers (schools and universities), where their local affiliation coexists with intercultural and multicultural forms of education, which presuppose the qualities of intellectual mobility of the personality. In the case of its socially adequate and humanistic philosophical position, every subject of education implements nationalpatriotic values that contributes to the formation of post-conventional patriotism (L. Kolberg) and highly developed moral consciousness.

\section{Conclusion.}

On the basis of the scientists' consideration of the self-identified personality phenomenon that develops and studies, and the research of the environment that determines this development in time, the person is determined to be the center, the subject of the educational environment, through positive changes of which we can talk about the effectiveness of such an environment, when it as significant element of society becomes a purposeful self-organized and managed multifunctional open pedagogical system, within which a person realizes oneself as a socially developed integrity.

Identity as the result of selfdetermination of a personality in such circumstances arises as a problem of person's finding the meaning of life and of oneself in the realm of 
sociocultural and personal values, is environment in view of the the concept that provides an effectiveness of the growth of subject opportunity to analyze the educational activity, comfort and its participants.

\section{REFERENCES}

1. Bart, R. (1987). Kritika i istina [Criticism and Truth]. Zarubezhnaya estetika i teoriya literaturyi XIX-XX vv.: Traktatyi, stati, esse [Foreign aesthetics and the theory of literature of the 19th-20th centuries: Treatises, essays, essays]. Moscow: MGU, 349-387.

2. Weber, M. (1998). Pro deiaki katehorii sotsiolohii rozuminnia. Sotsiolohiya. Zahalnoistorychni analizy. Polityka [On some categories of sociology of understanding. Sociology. General historical analysis. Policy]. Kyiv: Osnovy.

3. Weber, M. (1990). Izbrannyie proizvedeniya [Selected works]. Moscow: Progress.

4. Ilenkov, E. V. (2010). Chto takoe lichnost? Filosofiya i kultura [What is a personality? Philosophy and culture]. Moscow: Izdatelstvo Moskovskogo psihologo-sotsialnogo instituta. Voronezh: Izdatelstvo NPO «MODEK».

5. Klepko, S. F. (2005). Intehratsiya i polimorfizm znannia u vyshchiy osviti. Chastyna I. Fundamentalni problemy filosofii osvity [Integration and polymorphism of knowledge in higher education. Part I. Fundamental problems of the philosophy of education]. Filosofiya osvity, 2, 2034.

6. Kravchenko, L. M. (2006). Neperervna pedahohichna pidhotovka menedzhera osvity [Continuous pedagogical training of the education manager]. Poltava: Technoservice.

7. Kultaeva, M. D. (1988). Filosofsko-pedagogicheskie tendentsii v sovremennom idealizme [Philosophical and pedagogical tendencies in modern idealism]. Kharkiv: Izdatelstvo Harkovskogo gosudarsvennogo universiteta izdatelskogo obedineniya «Vischa shkola».

8. Marchenko, O. (2011). Osobystist v osvitnomu prostori modernu: priorytety ta vektory rozvytku [Personality in the modern educational space: priorities and development vectors]. Skhid, 2 (109), 123-127.

9. Maslow, A. (1991). Motivatsiya i lichnost [Motivation and personality]. Vestnik Moskovskogo universiteta. Seriya 7. Filosofiya, 3, 66-75.

10. Mead, D. (1994). Internalizirovannyie drugie i samost. Amerikanskaya sotsiologicheskaya mysl [Internalized others are the self. American sociological thought]. Moscow: Izdatelstvo MGU.

11. Oleksenko, R. I. (2013). Filosofiia rynkovykh vidnosyn. Stanovlennia ta rozvytok v Ukraini $\mathrm{v}$ period hlobalizatsiyi ta informatsiynoi revoliutsiyi: sotsialno-filosofskyi analiz [Philosophy of market relations. Formation and development in Ukraine during the period of globalization and information revolution: social-philosophical analysis]. Kyiv: Knowledge of Ukraine.

12. Saiuk, P. (2001). Zmina paradyhm sotsialnykh nauk i transformatsiya kultur osvitnoho prostoru na mezhi tysiacholit [Changing the paradigms of social sciences and the transformation of cultures of educational space at the turn of the millennium]. Osvita i upravlinnia [Education and Management], 4, 26-30.

13. Habermas, Yu. (1995). Demokratiya. Razum. Nravstvennost. Moskovskie lektsii i intervyu [Democracy. Reason. Morality. Moscow lectures and interviews]. Moscow: AO «KAMI». Publishing Center «ACADEMIA».

14. Shaposhnikova, I. V. (2015). Sotsiokulturni transformatsiyi: spivvidnoshennia tradytsiyi ta novatsiyi [Socio-cultural transformations: the ratio of traditions and innovations]. Hrani. Sotsiolohiya, 4 (120), 21-26.

15. Erickson, E. (2006). Identichnost: yunost i krizis [Identity: youth and crisis]. Moscow: Flint; MPSI; Progress.

16. Ryzhova, I. S. (2009). Dyzain v tekhnichnykh vuzakh Ukrainy. Humanitarnyi visnyk Zaporizkoi derzhavnoi inzhenernoi akademiyi, 37, 87-95.

Identity as a result of the self-determination of the personality in the educational environment 
ВАСЮК Ю. А. - аспірант Мелітопольського державного педагогічного університету імені Богдані Хмельницького (Мелітополь, Україна).

E-mail: 617811@ukr.net ORCID 0000-0002-5296-4851

\section{ІДЕНТИЧНІСТЬ ЯК РЕЗУЛЬТАТ САМОВИЗНАЧЕНОСТІ ОСОБИСТОСТІ В ОСВІТНЬОМУ СЕРЕДОВИЩІ}

Анотація. Актуальність теми зумовлена тим, що самоідентичність як ідентичність суб'єкта і результат його самовизначеності пояснюється нині двостороннім сходженням людини до свободи, коли спочатку суб'єкт усвідомлює необхідність саморозкриття власної сутності, втілення людської природи, а потім відбувається подолання ним залежності від своєї внутрішньої природи і розпочинається генерування ідентичності як вияву свободи волі й творчості людини культури.

Метою дослідження $є$ 3'ясування сутності і значення ідентичності особистості як результату iii самовизначеності в освітньому середовищі. Завдання дослідження: виокремлення ліній теоретичної інтерпретації ідентичності особистості; характеристика ідентичності як форми особистісного буття в освітньому середовищі, котра в ідеалі інтегрує на суб'єктивному рівні внутрішній світ людини і ії зовнішній світ у єдиний психосоціальний всесвіт; з'ясування принципових аспектів розуміння особистісної ідентичності, iii головних чинників у рамках спільної структури освітнього середовища; розгляд явища ідентичності 3 точки зору суб'єкта у контексті проблеми інтерсуб'єктивності. Аналіз останніх досліджень і публікацій, у яких започатковано розв'язання цієї проблеми: використання статей авторів Bart R. (1987), Weber M. (1998), Ilenkov E. (2010), Klepko S. (2005), Kultaieva M. (1988), Olexenko R. (2013).

Наукова новизна міститься у виявленні високої ролі взаємодії в освітньому середовищі на міжкультурному рівні, обумовленої загальним ставленням до суб'єкта як представника тієї чи іншої групи суб'єктів освітнього процесу, в окресленні змістового діапазону ідентичності (своєрідний освітній епіцентр життєвого циклу «людини культури» як суб'єкта освітніх процесів; самореферентність; єдність сталості й мінливості; усвідомлення особистістю своєї приналежності до тієї чи іншої соціально-особистісної позиції в контексті соціальних ролей освітнього середовища; самобутність і своєрідність; тотожність, еквівалентність; пропорційна відповідність; сутнісна подібність; співпадіння; самоототожнення з нормами й цінностями освітнього середовища, його конкретного рівня).

Результати дослідження: особистість визначено тим центром, суб'єктом освітнього середовища, через позитивні зміни якого можна говорити про ефективність цього середовища, коли воно як суттєвий елемент соціуму стає самоорганізованою і керованою багатофункціональною відкритою педагогічною системою, в межах якої особистість усвідомлює себе соціально розвиненою цілісністю. Висновок: ідентичність як результат самовизначеності особистості в обставинах освітнього середовища виникає як проблема знаходження людиною сенсу життя й самої себе у царині соціокультурних і особистісних цінностей, є тим концептом, який надає можливість аналізу цього середовища 3 погляду результативності зростання самосвідомості та суб’єктної активності його учасників.

Ключові слова: людина культури, освітнє середовище, самовизначеність особистості, ідентичність, змістовий діапазон ідентичності.

ВАСЮК Ю.А. - аспирант Мелитопольского государственного педагогического университета имени Богдана Хмельницкого (Мелитополь, Украина).

E-mail: 617811@ukr.net ORCID 0000-0002-5296-4851

\section{ИДЕНТИЧНОСТЬ КАК РЕЗУЛЬТАТ САМООПРЕДЕЛЕННОСТИ ЛИЧНОСТИ В ОБРАЗОВАТЕЛЬНЙ СРЕДЕ}

Аннотация. Актуальность темы обусловлена тем, что самоидентичность как идентичность субъекта и результат его самоопределения объясняется в современности двусторонним восхождением человека к свободе, когда сначала субъект осознает необходимость самораскрытия собственной сущности, воплощения человеческой природы, 
а затем происходит преодоление им зависимости от своей внутренней природы и происходит генерирование идентичности как проявления свободы воли и творчества человека культуры.

Целью исследования является выяснение сущности и значения идентичности личности как результата ее самоопределения в образовательной среде. Задачи исследования: выделение линий теоретической интерпретации идентичности личности; характеристика идентичности как формы личностного бытия в образовательной среде, которая в идеале интегрирует на субъективном уровне внутренний мир человека и его внешний мир в единую психо-социальную целостность; выяснение принципиальных аспектов понимания личностной идентичности, ее главных факторов в рамках структуры образовательной среды; рассмотрение явления идентичности с точки зрения субъекта в контексте проблемы интерсубъективности. Анализ последних исследований и публикаций, из которых начато решение этой проблемы: использование статей авторов Bart R. (1987), Weber M. (1998), Ilenkov E. (2010) Klepko S. (2005), Kultaieva M. (1988), Olexenko R. (2013).

Научная новизна содержится в выявлении высокой роли взаимодействия в образовательной среде на межкультурном уровне, обусловленной общим отношением к субъекту как представителю той или иной группы субъектов образовательного процесса, в определение содержательного диапазона идентичности (своеобразный образовательный эпицентр жизненного цикла «человека культуры» как субъекта образовательных процессов; самореферентность; единство устойчивости и изменчивости; осознание личностью наличия той или иной собственной социально-личностной позиции в контексте социальных ролей образовательной среды; самобытность и своеобразие; тождество, эквивалентность; пропорциональное соответствие; сущностное сходство; совпадение; самоотождествление с нормами и ценностями образовательной среды, ее конкретного уровня). Результаты исследования: личность определена тем центром, субъектом образовательной среды, через положительные изменения которого можно говорить об эффективности такой среды, когда она как существенный элемент социума становится самоорганизованной и управляемой многофункциональной открытой педагогической системой, в рамках которой личность осознает себя социально развитой целостностью.

Вывод: идентичность как результат самоопределения личности в обстоятельствах образовательной среды возникает как проблема нахождения человеком смысла жизни и самого себя в области социокультурных и личностных ценностей, является тем концептом, который предоставляет возможность анализа этой среды с точки зрения результативности роста самосознания и субъектной активности участников.

Ключевые слова: человек культуры, образовательная среда, самоопределение личности, идентичность, содержательный диапазон идентичности.

таття рекомендована до публікаиї̈ д. філос. н., проф. Д. І. Дзвінчук
(Івано-Франківськ, Украӥна)
Надійила до редколегї: 14.03 .2019 p.
Прийнята до друку: 24.03.2019 p

Identity as a result of the self-determination of the personality in the educational environment 